\title{
Glycosylated proteins identified for the first time in the alga
}

\section{Euglena gracilis}

Ellis O’Neill ${ }^{1}$

${ }^{1}$ School of Chemistry, University of Nottingham, University Park, Nottingham, NG7 2RD, UK;

* Correspondence: ellis.oneill@notttingham.ac.uk

\begin{abstract}
Protein glycosylation, and in particular $N$-linked glycans, is a hall mark of Eukaryotic cells and has been well studied in mammalian cells and parasites. However, little research has been conducted to investigate the conservation and variation of protein glycosylation pathways in other eukaryotic organisms. Euglena gracilis is an industrially important microalga, used in the production of biofuels and nutritional supplements. It is evolutionarily highly divergent from green algae and more related to Kinetoplastid pathogens. It was recently shown that $E$. gracilis possesses the machinery for producing a range of protein glycosylations and make simple $\mathrm{N}$ glycans, but the modified proteins were not identified. This study identifies the glycosylated proteins, including transporters, extra cellular proteases and those involved in cell surface signalling. Notably, many of the most highly expressed and glycosylated proteins are not related to any known sequences and are therefore likely to be involved in important novel functions in Euglena.
\end{abstract}

\section{Introduction}

Euglena are a class of mixotrophic protozoa that live in predominantly freshwater aquatic environments. ${ }^{1}$ Most possess a green secondary plastid derived by endosymbiosis of a chlorophyte algae, ${ }^{2}$ and there have been at least four endosymbiotic genome transfers, as well as significant horizontal gene transfer, during their evolutionary history. ${ }^{3}$ Uniquely among plastid containing cells, the chloroplast can be lost from photosynthetic Euglena without compromising their viability, due to duplication of all major pathways present in the chloroplast elsewhere in the cell. ${ }^{4}$ Euglenids are related to the well-known Kinetoplastid unicellular parasites Trypanosoma and Leishmania, as part of the phylum Euglenozoa. ${ }^{5}$ Euglena have been subject to scientific study for hundreds of years, but have recently become more intensely researched due to their considerable potential for biotechnological exploitation. ${ }^{6}$

Euglena gracilis, the most well characterised member of this group, has been studied for the production of vitamins $A, C, E,{ }^{7}$ essential amino acids, and polyunsaturated fatty acids. ${ }^{8}$ The storage polysaccharide, paramylon, ${ }^{9}$ makes up to $85 \%$ of algal dry weight when grown 
aerobically in light, whilst under anaerobic conditions wax esters can make up over $50 \%$ of the dry weight. ${ }^{10}$ These high value components have led to $E$. gracilis being cultivated as a food supplement. ${ }^{11}$ Recent work on the transcriptome and genome of E. gracilis has revealed the biosynthetic pathways for these valuable compounds. ${ }^{12,13}$

Euglena have been reported to have complex carbohydrates bound to their surface ${ }^{14,15}$ and lectin- and antibody-based profiling revealed a complex glycan surface, with some similarities to plant galactans and xylans. ${ }^{16}$ There are a wide range of carbohydrate active enzymes in the E. gracilis transcriptome, implying a capability for the synthesis of complex carbohydrates, ${ }^{17}$ and the cells contain a wide range of the sugar nucleotides needed as substrates for the synthesis of these polysaccharides. ${ }^{16}$ The exact nature of the complex surface carbohydrates in Euglena remains to be uncovered.

Protein glycosylation is a major post-translational modification in Eukaryotic organisms, stabilising surface proteins and providing specific intercellular interactions. ${ }^{18}$ Euglena gracilis expresses a range of enzymes necessary for the glycosylation of proteins: it has all of the genes necessary for the biosynthesis of GPI anchors, which anchor proteins into the phospholipid bilayer via a sugar-lipid tag, including the key transamidase for attaching the protein; ${ }^{12}$ there are three members of the GT41 family of glycosyltransferases, which transfer $\mathrm{N}$-acetylglucosamine to serine and threonine residues of proteins in the cytosol; ${ }^{17} \mathrm{~N}$ acetylglucosamine-1-phosphate transferase activity has been detected in membrane preparations of $E$. gracilis cells, ${ }^{19}$ likely involved in modifying proteins to target them to different subcellular compartments; sequences for all of the enzymes required for the synthesis of the highly conserved $\mathrm{N}$-glycan precursor can be identified in the transcriptome, as well as three sequences for the transferases that transfer this pre-formed oligosaccharide to the target proteins. ${ }^{12}$ Together these results that Euglena encodes the ability to form complex posttranslational glycosylation of proteins. Protein $\mathrm{N}$-glycan profiling of $E$. gracilis revealed that there was indeed protein glycosylation, mostly with high mannose type glycans with a small proportion modified with aminoethylphosphonate. ${ }^{16}$ No evidence was found for complex $\mathrm{N}$-glycans or for O-linked glycans on Euglena proteins and the proteins carrying these modifications were not identified..

This study uses lectin mediated protein isolation and proteomic analysis to identify the proteins which are decorated with these glycans in order to understand the contribution of protein glycosylation to the Euglena proteome and inform future production of pharmaceutical proteins. 


\section{Results}

Using standard proteomic techniques, the total proteome, glycan containing proteome and extracellular proteome were analysed from Euglena gracilis grown in a high yielding mixotrophic culture. It is notable that many of the most abundant proteins in all of the experimental samples in this study, as in previous work, ${ }^{13}$ are not linked to known sequences using BLAST. Many of those that do have known related sequences cannot be associated with GO terms or predicted functions, and together this indicates that some of the most highly abundant proteins in E. gracilis have no known function. It should also be noted that, due to limitations with the analytical techniques, the failure to detect a protein does not confirm its absence, but that it may not produce detectable peptides, be below the limit of detection or be masked by other, much more abundant, proteins.

The asparagine which is glycosylated can be identified by a mass deviation of 1 Dalton (Da) from the expected mass, caused by the cleavage of the $N$-glycan by PNGase-F treatment during the sample preparation. Peptides may not be detected in the modified form and the protein may be identified by other peptides, and so absence of this signal does not indicate absence of glycosylation of a protein. Only 88 of the 382 peptides annotated as containing this $N$-deamidation, appear to have the canonical NX(S/T) recognition signal for glycosylation. Whilst chemical deamidation of asparagine can occur giving rise to false identification of glycosylation sites, ${ }^{20}$ the high ratio of non-canonical sites in this data set raises serious concerns with the use of protein glycosylation site prediction tools that rely on this recognition motif for Euglena and indicates that there may be some other signal to target glycosylation in this organism. There are three sequences for the GT66 oligosaccharyltransferases that transfer the pre-formed glycan to the protein asparagine encoded in the Euglena transcriptome ${ }^{12}$ and it is possible that these have different specificities. Further experiments would be required to validate the true glycosylation sites.

\subsection{Total proteins}

1309 proteins were detected in all samples from the total proteome (see Supplementary Data), and of these $63 \%$ (836) have identified GO terms (see Figure 1), much higher than the $37 \%$ of the total transcripts which have GO terms mapped. ${ }^{12}$ Of the 130 proteins detected above the average, 30 do not have any BLAST hits, and 85 have GO terms identified. This indicates that the proteins that can be detected are less likely than those predicted from the transcriptome to have no known related sequences, possibly indicating the many of the predicted but unknown proteins are produced at a lower level or not at all. However, there are still many proteins that are unique to Euglena that are produced at relatively high levels and would repay further study. 


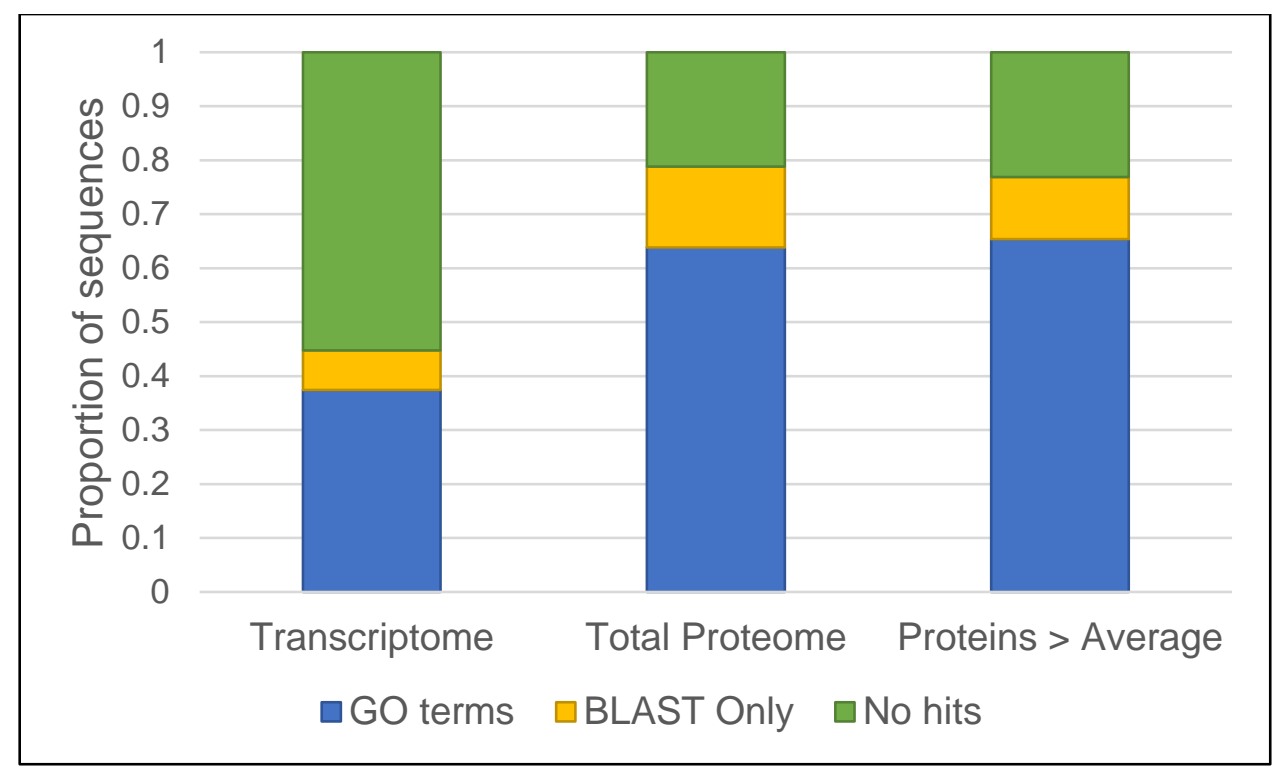

Figure 1: Euglena sequence identification. Proportion of sequences with identified GO terms and BLAST hits (blue), BLAST hits only (yellow) and neither (green) using Blast2GO, in the E. gracilis transcriptome, ${ }^{12}$ total proteome and proteins detected above average (this study).

In order to identify the likely subcellular location of these abundant proteins, protein targeting predictions were performed, using bioinformatic tools that have previously been used for Euglena proteins. ${ }^{4}$ Protein transport into Euglena chloroplasts occurs first via the secretory pathway and the Golgi apparatus using a secretion signal, followed by targeting to the chloroplast using a plastid targeting signal. ${ }^{21}$ Therefore, to confirm whether a protein was truly secreted or sent to the chloroplast, any predicted signal peptides were removed and the prediction repeated, revealing any masked plastid targeting signal. Target $\mathrm{P}^{22}$ predicted that four of the 20 most abundant proteins are targeted to the mitochondria, two to the chloroplast and one secreted, whilst WoLF PSORT ${ }^{23}$ predicts six to be targeted to the chloroplast, four to the mitochondria and one secreted (see Table 1). These results suggest the chloroplast and mitochondria contain some of the most abundant proteins in the cell.

\subsection{ConA Glycoprotein Isolation}

Concanavalin A (ConA) is a protein that specifically binds mannose, such as is found in simple $\mathrm{N}$-glycans, and glucose which can be found on the termini of $\mathrm{N}$-glycans. Using an immobilised ConA column to enrich for $\mathrm{N}$-glycan displaying proteins, a total of 86 proteins were detected at a significantly higher rate than in the total proteome, and 50 of these were not detected in the total proteome at all (See Table 2). 36 of these ConA enriched proteins had BLAST matches and 30 mapped to GO terms. Six of these are likely to be involved in signalling, three in sugar metabolism, two in transport, and there are four likely proteases. There are four proteins that are linked to biosynthesis, two to redox balance, and 12 involved in core housekeeping roles, which would expect to be cytosolic and thus not glycosylated. 13 of the 
86 proteins had an $\mathrm{N}$-deamidation site detected in at least one of the samples. Of the proposed cytosolic housekeeping genes this modification was noted in: 7967, a trypanothione reductase that has a deamidation site in all ConA samples, as well as the single WGA sample in which it was detected; 5325, a small nucleolar ribonucleoprotein U3, with one $\mathrm{N}$-deamidation site in just one ConA sample; 32750, a RNA scaffolding Sm-like protein, with deamidation in all WGA samples, although it was not detected significantly over the control in them, but not with no deamidation detected in any of the ConA samples. Only six of the ConA enriched proteins were predicted to be secreted, again highlighting the limitations of predicting protein targeting in protozoa.

\subsection{WGA Glycoprotein Isolation}

Wheat Germ Agglutinin (WGA) is a protein that specifically binds GlcNAc (or sialic acid, which is not present in Euglena ${ }^{16}$ ), found in the core of $\mathrm{N}$-glycans. A total of 675 proteins were detected in the sample eluted from the WGA Glycoprotein Isolation column. Of these, 16 were detected at a statistically significant rate higher than in the total cellular proteome (see Table $3)$, of which six were also detected in the ConA Glycoprotein Isolation sample. Just six of the 16 had matches in the non-redundant protein database and just four of these mapped to GO terms. These are a protein possibly involved in DNA repair, an oxidoreductase, a protein likely involved in retrograde signalling, and an integral membrane protease. It is possible that the WGA enriched proteins also contain an O-GIcNAc residue, a cytosolic protein modification found in eukaryotes with a role in cellular signalling and nutrient response. ${ }^{24}$

\subsection{Extracellular proteome}

As well as proteins isolated by lectin meditated enrichment, the extracellular proteome was analysed. These proteins were isolated from the cell-free media, and it should be noted that a small amount of extracellular media was included in the cell preparation for all other samples. A total of 135 proteins were detected in all three samples of the extra cellular proteome, of which 41 were not detected in the total proteome at all. 20 of these were statistically significantly more prevalent than in the total proteome (see Table 4), and of these only three had no BLAST matches (and only one further did not map to a GO term, despite matching a bacterial subtilisin related peptidase by BLAST). There are several proteins involved in transport and signalling. There is also a carbonic anhydrase, a thioredoxin, a peptidyl-prolyl cis-trans isomerase, a glycine dehydrogenase, and interestingly a possible protease inhibitor that could potentially be involved in pathogen resistance. ${ }^{25}$ There are also several proteins that would not be expected to be extracellular, such as a serine/threonine phosphatase, a chlorophyll binding protein and a CoA ligase. Interestingly the first and third most abundant proteins, also overrepresented in the ConA samples, do not match any sequences by BLAST. 


\section{Discussion}

As expected, the most abundant proteins in the total proteome were those associated with core housekeeping roles, central metabolism and the chloroplasts and mitochondria. Both ConA and WGA were able to enrich for a range of proteins, with some overlap, and the roles some of them may play on the cell surface can be postulated. The extracellular proteome has a number of proteins that could be involved in degrading extracellular material and signalling. The $N$-glycosylation site can be identified in some of the peptides, but it is notable that they are not reliably found at the canonical $N X(S / T)$ sites of other Eukaryotes.

Of particular note are the large number of unique proteins, unrelated to any previously identified proteins, that are highly abundant in the total proteome, in the glycoprotein isolation samples and in the extracellular proteome. There are also several proteins which are only related to "predicted protein" and with no GO terms identified using Blast2GO. This data indicates there are a large number of highly abundant proteins in Euglena with no known function, some of which we can now tentatively identify as being glycosylated. These unique proteins would repay further study.

\section{Methods}

\subsection{Culturing}

Euglena gracilis Z (CCAP1224/5Z) was grown in $15 \mathrm{ml}$ of EG:JM + glucose $(15 \mathrm{~g} / \mathrm{L})$ at $30^{\circ} \mathrm{C}$ with shaking (50 rpm) and illumination (800 lx) until late log phase (10 days) in triplicate. Cells were harvested by centrifugation $(1000 \mathrm{xg})$ and resuspended in supernatant $(1 \mathrm{ml})$.

\subsection{Extra cellular proteins}

The supernatant from the cell culture was filtered $(0.2 \mu \mathrm{m})$ and lyophilised. The material was dissolved in ammonium bicarbonate $(2.5 \mathrm{ml}, 50 \mathrm{mM})$ and desalted using a PD 10 column (Amersham Pharmacia Biotech AG) equilibrated and eluted with ammonium bicarbonate (50 $\mathrm{mM})$ the resultant material was again lyophilised and dissolved in $\mathrm{MQ} \mathrm{H}_{2} \mathrm{O}(0.4 \mathrm{ml})$.

\subsection{Glycoprotein preparation}

The resuspended Euglena cells from the culturing $(1 \mathrm{ml})$ were diluted with $5 x$ Binding/Wash buffer $(0.25 \mathrm{ml})$ containing phenylmethylsulfonyl fluoride $(2 \mathrm{mM})$ and lysed by sonication $(3 \mathrm{x}$ $10 \mathrm{~s}, 25 \%$ amplitude, $30 \mathrm{~s}$ off between each pulse) and centrifuged (5 min, $1000 \mathrm{xg}$ ). Not all cells were lysed. Total lysate containing the equivalent of $1.1 \mathrm{mg}$ of protein (Easy Bradford BioRad, BSA standards) was then used for glycoprotein purification using both ConA and WGA Glycoprotein Isolation Kits (Thermo Scientific) according to the manufacturer's instructions. Protein quality was assed using silver stained SDS-PAGE (Bolt 4-12\% Bis-TRIS 
plus, Invitrogen) using SeeBlue Plus2 Pre-stained Protein Standard (Thermo Fisher Scientific) as the standard.

\subsection{Protein digestion and analysis by mass spectrometry}

Protein digestion and analysis was performed by The Advanced Proteomics Facility at Oxford University. Protein samples were digested according to the Filter-Aided Sample Preparation (FASP) procedure. ${ }^{26}$ Peptide digest was treated with PNGase F and analysed by nano-liquid chromatography tandem mass spectrometry (nano-LC/MS/MS) on an Orbitrap Elite ${ }^{\mathrm{TM}}$ Hybrid Ion Trap-Orbitrap Mass Spectrometer (Thermo Scientific) using CID fragmentation. Peptides were loaded on a C18 PepMap100 pre-column (300 $\mu$ m i.d. x 5 mm, 100Å, Thermo Fisher Scientific) at a flow rate of $12 \mu \mathrm{L} / \mathrm{min}$ in $100 \%$ buffer $\mathrm{A}(0.1 \%$ formic acid (FA) in water). Peptides were then transferred to an in-house packed analytical column heated at $45^{\circ} \mathrm{C}$ (50cm, $75 \mu \mathrm{m}$ i.d. packed with ReproSil-Pur 120 C18-AQ, $1.9 \mu \mathrm{m}, 120 \AA$, Dr. Maisch GmbH) and separated using a 60 min gradient from 8 to $30 \%$ buffer $B(0.1 \%$ FA in acetonitrile (ACN)) at a flow rate of $200 \mathrm{~nL} / \mathrm{min}$. Survey scans were acquired at 120,000 resolution to a scan range from 350 to $1500 \mathrm{~m} / \mathrm{z}$. The mass spectrometer was operated in a data-dependent mode to automatically switch between MS and MS/MS. The 10 most intense precursor ions were submitted to Collision-Induced Dissociation fragmentation using a precursor isolation width set to $1.5 \mathrm{Da}$ and a normalised collision energy of 35. Database search was carried out using MaxQuant (1.6.3.4) against the non-redundant Euglena proteome available at https://jicbio.nbi.ac.uk/euglena/, ${ }^{12}$ with default parameters and including Deamidation on Asn residues as variable modification for $\mathrm{N}$-glycosylation sites identification. The mass spectrometry proteomics data have been deposited to the ProteomeXchange Consortium via the PRIDE ${ }^{27}$ partner repository with the dataset identifier PXD030579

\subsection{Data Analysis}

All Total, ConA and WGA samples were normalised with respect to an average of the 165 proteins detected in every sample. The Ext and Total samples were normalised to an average of the 81 proteins detected in both of these samples. Proteins that were differentially detected between the different treatments and the total proteome $(P<0.05$, Student's T-test, two tail) were included in further analysis. Using Blast2GO, protein sequences were matched to sequences in the NCBI non-redundant protein sequence database and assigned GO terms based on this.

\section{Supplementary Data}

"Euglena glycoproteomics raw data" contains the raw data including the proteins, peptides, modifications and $\mathrm{N}$-deamidation sites detected. "Euglena glycoproteomics data analysis" contains the data processed for all samples 


\section{Acknowledgments}

This research was funded by a Glasstone Fellowship and a Nottingham Research Fellowship awarded to E. O'Neill. I would like to thank Rob Field, Eve Roxborough and Callum Southwood for helpful discussions of the manuscript.

\section{References}

1 Buetow, D. E. The biology of Euglena: general biology and ultrastructure. (Academic Press, 1968).

2 Zakryś, B., Milanowski, R. \& Karnkowska, A. in Euglena: Biochemistry, Cell and Molecular Biology (eds Steven D. Schwartzbach \& Shigeru Shigeoka) 3-17 (Springer International Publishing, 2017).

3 Henze, K., Badr, A., Wettern, M., Cerff, R. \& Martin, W. A nuclear gene of eubacterial origin in Euglena gracilis reflects cryptic endosymbioses during protist evolution. Proceedings of the National Academy of Sciences 92, 9122-9126 (1995).

4 Inwongwan, S., Kruger, N. J., Ratcliffe, R. G. \& O’Neill, E. C. Euglena Central Metabolic Pathways and Their Subcellular Locations. Metabolites 9, 115 (2019).

$5 \quad$ Adl, S. M. et al. Revisions to the Classification, Nomenclature, and Diversity of Eukaryotes. Journal of Eukaryotic Microbiology 66, 4-119, doi:10.1111/jeu.12691 (2019).

6 Gissibl, A., Sun, A., Care, A., Nevalainen, H. \& Sunna, A. Bioproducts From Euglena gracilis: Synthesis and Applications. Frontiers in Bioengineering and Biotechnology 7, doi:10.3389/fbioe.2019.00108 (2019).

7 Takeyama, H. et al. Production of antioxidant vitamins, $\beta$-carotene, vitamin $C$, and vitamin $\mathrm{E}$, by two-step culture of Euglena gracilis Z. Biotechnology and Bioengineering 53, 185-190, doi:10.1002/(sici)1097-0290(19970120)53:2<185::aid-bit8>3.0.c0;2-k (1997).

$8 \quad$ Korn, E. D. The fatty acids of Euglena gracilis. Journal of Lipid Research 5, 352-362 (1964).

9 Rodríguez-Zavala, J. S., Ortiz-Cruz, M. A., Mendoza-Hernández, G. \& Moreno-Sánchez, R. Increased synthesis of $\alpha$-tocopherol, paramylon and tyrosine by Euglena gracilis under conditions of high biomass production. Journal of Applied Microbiology 109, 2160-2172, doi:10.1111/j.1365-2672.2010.04848.x (2010).

10 Inui, H., Miyatake, K., Nakano, Y. \& Kitaoka, S. Wax ester fermentation in Euglena gracilis. Febs Letters 150, 89-93, doi:10.1016/0014-5793(82)81310-0 (1982).

11 Zeng, M. et al. Fatty acid and metabolomic profiling approaches differentiate heterotrophic and mixotrophic culture conditions in a microalgal food supplement'Euglena'. BMC biotechnology 16, 1-8 (2016).

12 O'Neill, E. C. et al. The transcriptome of Euglena gracilis reveals unexpected metabolic capabilities for carbohydrate and natural product biochemistry. Molecular Biosystems 11, 2808-2820, doi:10.1039/c5mb00319a (2015).

13 Ebenezer, T. E. et al. Transcriptome, proteome and draft genome of Euglena gracilis. BMC Biology 17, 11, doi:10.1186/s12915-019-0626-8 (2019).

14 Barras, D. R. \& Stone, B. A. Chemical composition of pellicle of Euglena gracilis var bacillaris. Biochemical Journal 97, 14-15 (1965).

15 Bouck, G. B., Rogalski, A. \& Valaitis, A. Surface organization and composition of Euglena. 2. Flagellar mastigonemes. Journal of Cell Biology 77, 805-826, doi:10.1083/jcb.77.3.805 (1978).

16 O'Neill, E. et al. Exploring the glycans of Euglena gracilis. Biology 6, 45 (2017).

17 O'Neill, E. C., Trick, M., Henrissat, B. \& Field, R. A. Euglena in time: Evolution, control of central metabolic processes and multi-domain proteins in carbohydrate and natural product biochemistry. Perspectives in Science 6, 84-93 (2015).

18 Varki, A. et al. in Essentials of Glycobiology (eds A. Varki et al.) (Cold Spring Harbor Laboratory Press 
Copyright 2015-2017 by The Consortium of Glycobiology Editors, La Jolla, California. All rights reserved., 2017).

19 Ivanova, I. M. et al. Fluorescent mannosides serve as acceptor substrates for glycosyltransferase and sugar-1-phosphate transferase activities in Euglena gracilis membranes. Carbohydrate Research 438, 26-38, doi:10.1016/j.carres.2016.11.017 (2017).

20 Palmisano, G., Melo-Braga, M. N., Engholm-Keller, K., Parker, B. L. \& Larsen, M. R. Chemical deamidation: a common pitfall in large-scale $\mathrm{N}$-linked glycoproteomic mass spectrometrybased analyses. J Proteome Res 11, 1949-1957, doi:10.1021/pr2011268 (2012).

21 Durnford, D. G. \& Gray, M. W. Analysis of Euglena gracilis plastid-targeted proteins reveals different classes of transit sequences. Eukaryotic Cell 5, 2079-2091 (2006).

22 Almagro Armenteros, J. J. et al. Detecting sequence signals in targeting peptides using deep learning. Life Science Alliance 2, e201900429, doi:10.26508/Isa.201900429 (2019).

23 Horton, P. et al. WoLF PSORT: protein localization predictor. Nucleic acids research 35, W585W587, doi:10.1093/nar/gkm259 (2007).

24 Zeidan, Q. \& Hart, G. W. The intersections between O-GlcNAcylation and phosphorylation: implications for multiple signaling pathways. Journal of Cell Science 123, 13-22, doi:10.1242/jcs.053678 (2010).

25 Jashni, M. K., Mehrabi, R., Collemare, J., Mesarich, C. H. \& de Wit, P. J. G. M. The battle in the apoplast: further insights into the roles of proteases and their inhibitors in plant-pathogen interactions. Frontiers in Plant Science 6, doi:10.3389/fpls.2015.00584 (2015).

26 Wiśniewski, J. R., Zougman, A., Nagaraj, N. \& Mann, M. Universal sample preparation method for proteome analysis. Nature Methods 6, 359-362, doi:10.1038/nmeth.1322 (2009).

27 Perez-Riverol, Y. et al. The PRIDE database and related tools and resources in 2019: improving support for quantification data. Nucleic Acids Res 47, D442-d450, doi:10.1093/nar/gky1106 (2019). 


\begin{tabular}{|c|c|c|c|c|c|}
\hline $\begin{array}{l}\text { Sequence } \\
\text { Name }\end{array}$ & Sequence Description & $\begin{array}{l}\text { Average } \\
\text { Intensity }\end{array}$ & StDev & $\begin{array}{c}\text { TargetP } \\
\text { prediction }^{22}\end{array}$ & $\begin{array}{c}\text { WoLF PSORT } \\
\text { prediction }^{23}\end{array}$ \\
\hline 16406 & Glyceraldehyde 3-phosphate dehydrogenase & 17.44805 & 0.036709 & Other & Cytosol \\
\hline 3371 & $\begin{array}{c}\text { Stromal } 70 \text { kDa heat shock-related protein, } \\
\text { chloroplastic-like }\end{array}$ & 13.07199 & 2.87894 & Chloroplast $^{*}$ & Chloroplast* $^{*}$ \\
\hline 12260 & Phosphoglycerate kinase & 9.826626 & 2.135535 & Other & Cytosol \\
\hline 8709 & Oxygen-evolving enhancer protein 1, chloroplastic & 9.502916 & 1.305499 & Chloroplast & Chloroplast \\
\hline 8430 & Putative mitochondrial heat-shock protein hsp70 & 9.346824 & 1.086321 & Other $^{*}$ & Cytosol $^{*}$ \\
\hline 6665 & Phosphopyruvate hydratase & 8.758831 & 0.565104 & Other* & Cytosol $^{*}$ \\
\hline 61646 & 60 s acidic ribosomal protein $\mathrm{p} 2$ & 7.992886 & 0.289941 & Other* & $\begin{array}{l}\text { Extracellular* } \\
\text { (Chloroplast) }\end{array}$ \\
\hline 4720 & NA & 7.732722 & 1.186309 & Other & Mitochondria \\
\hline 25934 & Oxygen-evolving enhancer protein 3 & 7.419665 & 1.114722 & $\begin{array}{l}\text { Signal Peptide } \\
\text { (Signal peptide) }\end{array}$ & Chloroplast \\
\hline 25617 & Electron transfer flavoprotein subunit alpha & 6.635908 & 1.382096 & Other* & Chloroplast* $^{*}$ \\
\hline 8433 & NA & 6.51502 & 0.534721 & Other & Nucleus \\
\hline 8912 & Putative ATPase beta subunit & 6.505054 & 1.134881 & Mitochondria* & Mitochondria* \\
\hline 12357 & Elongation factor 1-alpha & 5.914015 & 0.663056 & Other* & Cytosol $^{*}$ \\
\hline 14010 & Beta-tubulin & 5.45031 & 0.352232 & Other* & Nucleus* \\
\hline 7178 & Chaperonin HSP60, mitochondrial precursor & 4.972642 & 0.89093 & Mitochondria & Mitochondria \\
\hline 23135 & NA & 4.893481 & 0.05412 & Other* & Cytosol $^{*}$ \\
\hline 7258 & NA & 4.74644 & 0.335421 & Other & Nucleus \\
\hline 8679 & Putative dihydrolipoamide dehydrogenase & 4.417853 & 0.969253 & Mitochondria & Chloroplast \\
\hline 5458 & Molecular chaperone DnaK & 4.144819 & 2.138527 & Mitochondria & Mitochondria \\
\hline 4275 & ATPase beta subunit & 3.973031 & 1.009266 & Other & Chloroplast \\
\hline
\end{tabular}




\begin{tabular}{|c|c|c|c|c|c|c|c|}
\hline $\begin{array}{l}\text { Sequence } \\
\text { Name }\end{array}$ & $\begin{array}{c}\text { Sequence } \\
\text { Description }\end{array}$ & $\begin{array}{l}\text { Average } \\
\text { Intensity }\end{array}$ & StDev & $\begin{array}{c}\text { Ratio } \\
\text { ConA/Total } \\
\end{array}$ & P-value & $\begin{array}{l}\text { TargetP } \\
\text { prediction } 22\end{array}$ & $\begin{array}{l}\text { WoLF PSORT } \\
\text { prediction }^{23}\end{array}$ \\
\hline 14865 & Predicted protein & 32.96 & 12.00962 & 35.37 & 0.04 & Chloroplast* $^{*}$ & Chloroplast* $^{\star}$ \\
\hline 361 & NA & 7.87 & 2.317563 & 7.99 & 0.04 & Other* & Nucleus ${ }^{*}$ \\
\hline 17372 & $\begin{array}{c}\text { Vitamin B6 } \\
\text { biosynthesis protein }\end{array}$ & 5.03 & 0.737106 & 2.45 & 0.01 & Other & Cytoplasm \\
\hline 4137 & NA & 2.76 & 0.606286 & 13.92 & 0.02 & Other & Cytoplasm \\
\hline 53965 & $\begin{array}{l}\text { UV excision repair } \\
\text { protein Rad23 }\end{array}$ & 1.61 & 0.309176 & 5.77 & 0.02 & Other* & Cytoplasm* \\
\hline 15475 & $\begin{array}{c}\text { GDP-mannose } 4,6 \\
\text { dehydratase }\end{array}$ & 0.96 & 0.20172 & 3.30 & 0.01 & Other* & Cytoskeleton* \\
\hline 37872 & NA & 0.80 & 0.242691 & 12.38 & 0.03 & Other* & Nucleus* \\
\hline 538 & NA & 0.76 & 0.284298 & 102.61 & 0.04 & Other & Nucleus \\
\hline 22038 & $\begin{array}{c}\text { Charged multivesicular } \\
\text { body protein } 4 a\end{array}$ & 0.63 & 0.157675 & 2.94 & 0.04 & Other & Nucleus \\
\hline 32626 & $\begin{array}{l}\text { transcription factor } \\
\text { BTF3 homolog 4-like }\end{array}$ & 0.63 & 0.200439 & 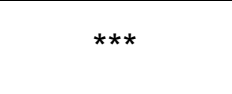 & 0.03 & Other & Nucleus \\
\hline
\end{tabular}


Table 3: Proteins enriched in WGA Glycoprotein Isolation. " Indicates proteins also identified as significantly enriched by ConA Glycoprotein Isolation. NA is sequences with no homologues identified by BLAST. ${ }^{* * *}$ are proteins not detected in the total protein sample. ${ }^{*}$ indicates sequences that do not start with a $\mathrm{M}$ and so may be truncated sequences that do not contain the targeting sequence present in the protein. Any secretory signal peptides identified were removed and the analysis repeated, with results shown in brackets.

\begin{tabular}{|c|c|c|c|c|c|c|c|}
\hline $\begin{array}{l}\text { Sequence } \\
\text { Name }\end{array}$ & Sequence Description & $\begin{array}{l}\text { Average } \\
\text { Intensity }\end{array}$ & StDev & $\begin{array}{c}\text { Ratio } \\
\text { WGA/Total }\end{array}$ & P-value & $\begin{array}{c}\text { TargetP } \\
\text { prediction }^{22}\end{array}$ & $\begin{array}{l}\text { WoLF PSORT } \\
\text { prediction }^{23}\end{array}$ \\
\hline 24159 & $\begin{array}{l}\text { UV excision repair protein } \\
\text { RAD23 homolog } B\end{array}$ & 1.571933 & 0.41 & 5.800405 & 0.027599 & Other* & Chloroplast* $^{*}$ \\
\hline $9057^{\#}$ & NA & 0.481899 & 0.17 & $\star \star *$ & 0.040911 & Other & Nucleus \\
\hline $20266^{\#}$ & $\begin{array}{c}\text { S-(hydroxymethyl) } \\
\text { glutathione } \\
\text { dehydrogenase/class III } \\
\text { alcohol dehydrogenase }\end{array}$ & 0.422701 & 0.12 & 6.008595 & 0.013053 & Other* & Cytoplasm* \\
\hline 19374 & NA & 0.369053 & 0.13 & 22.50882 & 0.048467 & Other* & Nucleus* \\
\hline 255 & $\begin{array}{c}\text { Kinesin-like protein } \\
\text { KIF16B }\end{array}$ & 0.187588 & 0.05 & 9.307156 & 0.026652 & Other & Cytoplasm \\
\hline $59^{\#}$ & NA & 0.14351 & 0.05 & 4.492779 & 0.029378 & Other & Cytoplasm \\
\hline 12064 & NA & 0.136116 & 0.04 & $\star * \star$ & 0.024536 & Other* & Cytoplasm* \\
\hline $27863^{\#}$ & NA & 0.108907 & 0.00 & $* * *$ & $3.44 \mathrm{E}-05$ & Other* & Mitochondria* \\
\hline $6278^{\#}$ & Predicted protein & 0.028572 & 0.01 & $* * *$ & 0.038147 & Other & Chloroplast \\
\hline 8504 & $\begin{array}{l}\text { NLR family CARD domain- } \\
\text { containing protein 3-like }\end{array}$ & 0.010453 & 0.01 & 2.631579 & 0.044291 & Other* & Nucleus* \\
\hline 4654 & S8 family serine peptidase & 0.007635 & 0.00 & *** & 0.013451 & $\begin{array}{l}\text { Signal } \\
\text { peptide } \\
\text { (Other) }\end{array}$ & Chloroplast \\
\hline
\end{tabular}


Table 4: Proteins enriched in Extracellular proteome. NA is sequences with no homologues identified by BLAST. *** are proteins not detected in the total protein sample. Any secretory signal peptides were removed and the analysis repeated, with results shown in brackets. * indicates sequences that do not start with a $\mathrm{M}$ and so may be truncated sequences that do not contain the targeting sequence present in the protein.

\begin{tabular}{|c|c|c|c|c|c|c|c|}
\hline $\begin{array}{c}\text { Sequence } \\
\text { Name }\end{array}$ & Sequence Description & $\begin{array}{l}\text { Average } \\
\text { Intensity }\end{array}$ & StDev & $\begin{array}{c}\text { Ratio } \\
\text { Ext/Total }\end{array}$ & P-value & $\begin{array}{c}\text { TargetP } \\
\text { prediction }^{22}\end{array}$ & $\begin{array}{l}\text { WoLF PSORT } \\
\text { prediction }^{23}\end{array}$ \\
\hline 2713 & NA & 72.80851 & 18.07437 & 20161.41 & 0.019932 & $\begin{array}{l}\text { Signal peptide } \\
\text { (Other) }\end{array}$ & $\begin{array}{c}\text { Extracellular } \\
\text { (Nuclear) }\end{array}$ \\
\hline 11740 & S8 family peptidase & 0.570963 & 0.084867 & $* * *$ & 0.007284 & $\begin{array}{l}\text { Signal peptide } \\
\text { (Other) }\end{array}$ & $\begin{array}{c}\text { Plasma } \\
\text { membrane }\end{array}$ \\
\hline 13218 & NA & 0.391458 & 0.058299 & 12426.41 & 0.007318 & $\begin{array}{l}\text { Signal peptide } \\
\text { (Other) }\end{array}$ & $\begin{array}{l}\text { Extracellular } \\
\text { (Cytosol) }\end{array}$ \\
\hline 3168 & $\begin{array}{c}\text { Long-chain-fatty-acid--CoA ligase } 4 \\
\text { isoform X1 }\end{array}$ & 0.226524 & 0.080067 & 2644.55 & 0.039249 & Other* & Chloroplast* $^{*}$ \\
\hline 18460 & Hypothetical protein, conserved & 0.166714 & 0.062074 & $* \star * \star$ & 0.043237 & Other $^{*}$ & Chloroplast* $^{*}$ \\
\hline 7055 & $\begin{array}{l}\text { Light-harvesting chlorophyll a/b-binding } \\
\text { protein }\end{array}$ & 0.14248 & 0.049539 & 45.55 & 0.039233 & Other* & $\begin{array}{c}\text { Plasma } \\
\text { membrane* }\end{array}$ \\
\hline 1245 & P-ATPase family transporter & 0.114422 & 0.030738 & $* \star *$ & 0.02322 & Other & $\begin{array}{c}\text { Plasma } \\
\text { membrane }\end{array}$ \\
\hline 19656 & Cystatin B, putative & 0.095887 & 0.036113 & $* \star * *$ & 0.044171 & Other & Cytosol \\
\hline 13679 & $\begin{array}{c}\text { Serine/threonine-protein phosphatase } \\
\text { PP-X isozyme } 2\end{array}$ & 0.085083 & 0.022593 & 71.53 & 0.023225 & Other & Cytosol \\
\hline 14610 & Carbonic anhydrase 1 & 0.061822 & 0.019603 & $* * *$ & 0.031917 & Other & Chloroplast \\
\hline 6287 & CocE/NonD family hydrolase & 0.060295 & 0.024003 & 291.81 & 0.048503 & Other* $^{*}$ & E.R.* \\
\hline 1548 & $\begin{array}{c}\text { aminomethyl-transferring glycine } \\
\text { dehydrogenase }\end{array}$ & 0.058086 & 0.01343 & 12.89 & 0.023302 & Mitochondria & Mitochondria \\
\hline 17754 & $\begin{array}{c}\text { pleiotropic drug resistance protein } \mathrm{ABC} \\
\text { superfamily }\end{array}$ & 0.055424 & 0.012081 & 480.24 & 0.015448 & Other* & Nucleus* \\
\hline 2873 & $\begin{array}{l}\text { probable inorganic phosphate transporter } \\
1-3\end{array}$ & 0.047583 & 0.013913 & $* * *$ & 0.027336 & Other* & $\begin{array}{c}\text { Plasma } \\
\text { membrane* }\end{array}$ \\
\hline 19178 & 14-3-3 protein & 0.042734 & 0.003681 & 7.18 & 0.003449 & Other & Nucleus \\
\hline
\end{tabular}




\begin{tabular}{|c|c|c|c|c|c|c|c|}
\hline 13675 & $\begin{array}{c}\text { Putative 3, 5-cyclic nucleotide } \\
\text { phosphodiesterase }\end{array}$ & 0.034218 & 0.0093 & $* * *$ & 0.023751 & Other & E.R. \\
\hline 1168 & $\begin{array}{c}\text { ATP-binding cassette sub-family G } \\
\text { member 2 isoform X1 }\end{array}$ & 0.033678 & 0.00752 & $* * *$ & 0.016218 & $\begin{array}{c}\text { Signal peptide } \\
\text { (Other) }\end{array}$ & $\begin{array}{c}\text { Plasma } \\
\text { membrane }\end{array}$ \\
\hline 34359 & Thioredoxin & 0.028584 & 0.007885 & 4.02 & 0.038769 & Mitochondria & Chloroplast \\
\hline 26116 & $\begin{array}{c}\text { Peptidyl-prolyl cis-trans isomerase } \\
\text { CYP19-3 }\end{array}$ & 0.016344 & 0.003933 & 5.14 & 0.033596 & Mitochondria & Chloroplast \\
\hline 27196 & NA & 0.015681 & 0.001283 & 130.58 & 0.002202 & Other $^{*}$ & Chloroplast $^{*}$ \\
\hline
\end{tabular}


bioRxiv preprint doi: https://doi.org/10.1101/2021.10.28.466288; this version posted January 5, 2022. The copyright holder for this preprint (which was not certified by peer review) is the author/funder, who has granted bioRxiv a license to display the preprint in perpetuity. It is made available under aCC-BY-NC 4.0 International license. 